\title{
Analisis Modulus Deformasi Massa Batuan pada Segmen Jalan USAID Km 27 Hingga Km 30 Berdasarkan Klasifikasi Massa Batuan
}

\author{
Ibnu Rusydy ${ }^{1,3^{*}}$, Nafisah Al-Huda ${ }^{1,2}$, M. Fahmi ${ }^{4}$, Naufal Effendi ${ }^{4}$, \\ Abrar Muslim ${ }^{4,5}$, Mirna Lubis ${ }^{4,5}$ \\ ${ }^{1}$ Program Studi Teknik Geologi, Fakultas Teknik, Universitas Syiah Kuala, Banda Aceh, Indonesia \\ ${ }^{2}$ Program Studi Teknik Sipil, Fakultas Teknik, Universitas Syiah Kuala, Banda Aceh, Indonesia \\ ${ }^{3}$ Tsunami dan Disaster Mitigation Research Center (TDMRC), Universitas Syiah Kuala, Banda Aceh, Indonesia \\ ${ }^{4}$ Program Studi Teknik Pertambangan, Fakultas Teknik, Universitas Syiah Kuala, Banda Aceh, Indonesia. \\ ${ }^{5}$ Program Studi Teknik Kimia, Fakultas Teknik, Universitas Syiah Kuala, Banda Aceh, Indonesia
}

\begin{abstract}
ABSTRAK Penelitian modulus deformasi dan klasifikasi massa batuan mengunakan sistem $R M R$ (rock mass rating) dan GSI (geological strength index) telah dilakukan di Jalan Raya USAID km 27 hingga $\mathrm{km}$ 30. Lintasan jalan di daerah ini berada pada batuan yang mengalami deformasi akibat aktivitas tektonik sehingga pada bagian lereng badan jalan ditemukan rekahan-rekahan yang berpotensi longsor, maka diperlukan rekayasa lereng dengan menganalisis dan menilai klasifikasi massa batuan. Penelitian ini bertujuan untuk mengidentifikasi klasifikasi massa batuan dengan RMR (rock mass rating), GSI (geological strength index), dan besaran nilai modulus deformasi massa batuan yang terdapat pada batugamping lempungan. Metode penelitian yaitu dengan melakukan scanline untuk mengambil data orientasi struktur geologi untuk analisis kinematik lereng dan kondisi bidang diskontinuitas (kemenerusan, bukaan, kekasaran, isian, tingkat pelapukan dan kondisi keairan), termasuk kekuatan batuan utuh yang diambil dari lereng batuan untuk menghitung nilai $R M R$ dan
\end{abstract}

Naskah masuk : 3 Oktober 2019

Naskah direvisi : 6 Februari 2020

Naskah diterima : 2 Juni 2020

*Penulis korespondensi.

Email: ibnu@unsyiah.ac.id
GSI. Pendekatan empiris dilakukan untuk mengestimasi nilai modulus deformasi berdasarkan nilai GSI. Hasil penelitian menunjukkan bahwa longsor batuan yang akan terjadi berdasarkan analisis kinematik adalah longsoran jenis planar, gulingan, dan baji. Nilai $R M R$ masing-masing lereng 1, 2, 3 dan 4 adalah sebesar 60, 64, 60, dan 61, sementara nilai GSI sebesar 50, 51, 52 dan 54 secara berurutan. Nilai modulus deformasi massa batuan untuk batugamping lempungan sebesar $50 \mathrm{GPa}$ untuk semua lereng.

Kata kunci: $R M R, G S I$, modulus deformasi batuan, lereng batuan, klasifikasi massa batuan

ABSTRACT - Rock mass modulus deformation analysis in USAID highways segment $\mathrm{km} 27^{\text {th }}$ to $\mathrm{km} 3 \mathrm{O}^{\text {th }}$ based on rock mass classifications. Rock mass modulus deformation and rock mass classifications utilizing RMR (rock mass rating) and GSI (geological strength index) have been conducted in USAID Highways segment from $\mathrm{km}$ $27^{\text {th }}$ to $\mathrm{km} 30^{\text {th }}$ where is built on the rocks which are highly influenced by tectonic force and deformed by tectonic activity; hence, the rock on the slopes are fractured, folded and potentially to failure. These circumstances need a rock engineering approach by applying rock mass classification methods. This research aims to identify the rock mass classifications based on RMR, GSI, and to estimate the rock mass modulus deformation working on rock slope of argillaceous limestone. Scanline approach was utilized in structural geology data acquisition for rock slope kinematic analysis and joints condition (persistence, aperture, roughness, infilling, 
weathering, and watering) included the strength of intact rock is obtained from rock slope in calculating the RMR and GSI ratings. The empirical approach was deployed in estimating the rock mass modulus deformation based on GSI value. Rock slope kinematic analysis reveals the possibility of rock failure that will be occurred on the slopes are plane, toppling, and wedge failures. The total RMR ratings are 60, 64, 60, and 61 for slope 1, 2, 3, and 4, while the total GSI values are $50,51,52$, and 54 respectively. Rock mass modulus deformation for argillaceous limestone in this study area is $50 \mathrm{GPa}$ for every slope.

Keywords: RMR, GSI, rock modulus deformation, rock slope, rock mass classifications

\section{PENDAHULUAN}

Dalam ilmu rekayasa batuan (rock engineering), massa batuan dikenal sebagai sebuah susunan blok-blok batuan yang memiliki banyak bidang diskontinuitas dan struktur geologi di dalamnya seperti bidang perlapisan (bedding), bidang patahan (fault), bidang rekahan (joint), dan lipatan (folding). Kualitas massa batuan sangat dipengaruhi oleh struktur geologi dan kondisi bidang diskontinuitas itu sendiri (Wyllie dan Mah, 2004; Pantelidis, 2009; Grelle et al., 2011; Siddique et al., 2015; Rusydy et al., 2016, 2017, 2019). Klassifikasi massa batuan merupakan tumpuan dasar dalam menganalisis kualitas massa batuan untuk tujuan pembangunan (Wyllie dan Mah, 2004). Salah satu klasifikasi massa batuan yang paling banyak digunakan untuk menganalisi kualitas massa batuan adalah $R M R$ (rock mass rating) dan GSI (geological strength index). Penelitian klasifikasi massa batuan menggunakan metode tersebut sudah pernah dilakukan oleh Gurocak et al. (2008) Pantelidis (2009), Lee dan Wang (2011), Siddique et al. (2015), Basahel dan Mitri (2017), dan Rusydy et al. (2017, 2019). Selain itu, nilai modulus deformasi massa batuan $\left(E_{r m}\right)$ bisa diestimasi berdasarkan nilai klasifikasi massa batuan GSI. Nilai modulus deformasi massa batuan dan kekuatan batuan menjadi input dasar bagi engineer untuk membuat pemodelan numerik kestabilan lereng dan terowongan (Cai et al., 2004).

Hasil observasi menunjukkan bahwa telah terjadi longsor pada beberapa titik lokasi jalan USAID (Banda Aceh - Calang) dan terdapat potensi longsor batuan lebih lanjut sepanjang trase jalan km 27 hingga $\mathrm{km}$ 30. Oleh karena itu perlu dilakukan kajian analisis kinematik untuk mengetahui jenis longsor batuan yang akan terjadi dan klasifikasi massa batuan guna mengetahui dan menilai kualitas batuan pembentuk lereng. Penelitian klasifikasi massa batuan RMR dan GSI ini bisa menjadi data dasar untuk menilai kualitas massa batuan pembentuk lereng. Penelitian ini bertujuan untuk mengetahui jenis longsor batuan berdasakan analisis kinematik lereng, mengetahui nilai kelas kualitas batuan berdasarkan klasifikasi $R M R$ dan GSI serta memprediksi nilai modulus deformasi massa batugamping lempungan yang terdapat di beberapa titik longsor batuan di jalur jalan tersebut.

\section{TATANAN GEOLOGI KAWASAN LEUPUNG}

\section{Geologi Regional}

Zona subduksi yang terbentuk di sisi Baratdaya Pulau Sumatra terbentuk akibat interaksi antara lempeng Indo-Australia dengan lempeng Eurasia dan sangat mempengaruhi struktur geologi sepanjang Pulau Sumatra (McCaffrey, 2009; Muksin et al., 2018; Rusydy et al., 2018, 2020). Arah zona subduksi yang miring (oblique) antara lempeng Indo-Australia dengan lempeng Eurasia menyebabkan terbentuknya Patahan Sumatra dengan mekanisme geser menganan sepanjang $1.900 \mathrm{~km}$ dari Selat Sunda sampai ke Provinsi Aceh (McCaffrey, 2009; Sieh dan Natawidjaja, 2000; Rusydy et al., 2018, 2020). Posisi Patahan Sumatra terhadap lokasi penelitian dapat dilihat pada Gambar 1b.

Zona subduksi dan Patahan Sumatra mengontrol seluruh struktur geologi yang terbentuk di daratan Aceh yang menyebabkan terbentuknya lipatan, rekahan, dan patahan yang bisa diamati pada batuan (Fernández-Blanco et al., 2016). Dalam bidang rekayasa batuan (rock engineering), struktur geologi tersebut dianggap sebagai bidang diskontinuitas yang mengontrol kualitas massa batuan (Grelle et al., 2011; Siddique et al., 2015; Rusydy et al., 2016, 2017, 2019).

\section{Geologi Lokal}

Kawasan penelitian terletak di Jalan Provinsi sisi barat Provinsi Aceh dari km 27 hingga km 30. Batuan yang terbentuk sepanjang jalan Kecamatan Leupung, Kabupaten Aceh Besar adalah batugamping lempungan yang memiliki banyak 

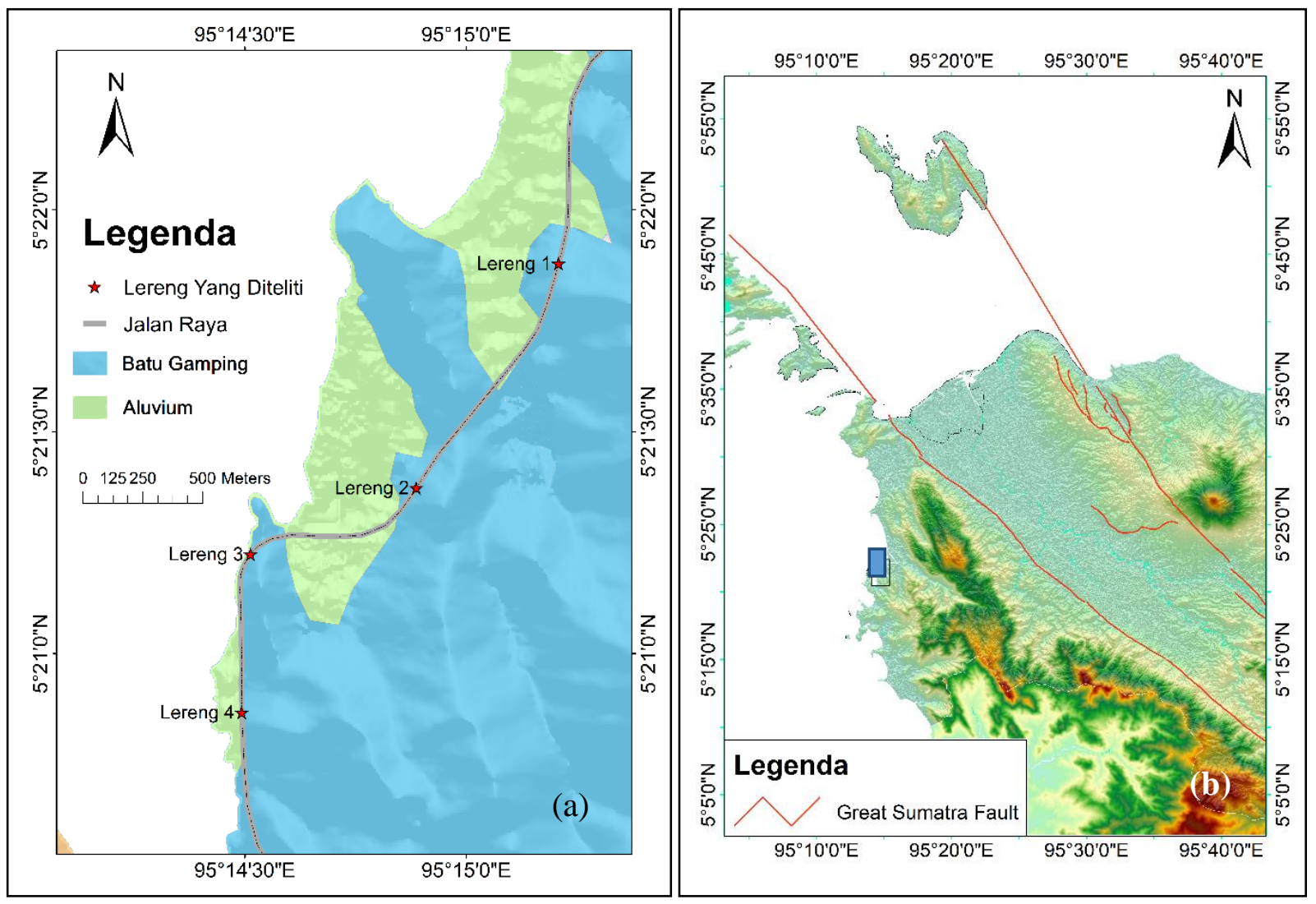

Gambar 1. (a) Lokasi lereng yang diteliti dan peta geologi kawasan penelitian yang terdiri dari batugamping lempungan dan endapan sedimen aluvium, peta geologi dibuatkan berdasarkan peta dari Bennet et al. (1981). (b) Lokasi penelitian yang ditunjukkan oleh kotak biru dan lokasi Patahan Sumatra.

bidang diskontinuitas dan terlipatkan akibat gaya tektonik dari zona subduksi atau Patahan Sumatra.

Menurut Barber (2000), Barber dan Crow (2005), batugamping lempungan di lokasi penelitian terbentuk pada zaman Jura Akhir (sekitar 163.5 juta tahun lalu) sampai dengan zaman Kapur Awal (sekitar 100.5 juta tahun lalu). Bennet et al. (1981), Barber (2000), Barber dan Crow (2005) menyatakan bahwa batugamping tersebut merupakan bagian dari group Woyla yang terbentuk dari akresi sedimen laut. Zona akresi dikenal sebagai zona yang sangat dipengaruhi oleh gaya tektonik sehingga sangat berlipat dan memiliki rekahan atau hancuran yang tinggi. Rusydy et al. $(2017,2019)$ mencatat bahwa lereng batu yang terbentuk sepanjang jalan tersebut terdiri dari blok-blok batu, lipatan batuan, dan perlapisan batuan yang banyak sehingga sepanjang jalan tersebut rawan terjadinya longsor batuan. Namun demikian, sebagian besar masyarakat Kecamatan Leupung tinggal di kawasan alluvium yang aman dari ancaman longsor batuan, namun longsor batuan tersebut akan menganggu jalur transportasi dan ekonomi masyarakat yang tinggal di pantai barat dan selatan Provinsi Aceh.

\section{METODE}

Metode penelitian yang dilakukan meliputi pengamatan lapangan dan pengukuran struktur massa batuan menggunakan metode scanline berdasarkan Brown (1981) pada 4 lokasi. Data yang diambil berupa kemiringan lereng, arah lereng, kemiringan dan arah bidang diskontinuitas, jarak antar bidang diskontinuitas, karakter bidang diskontinuitas, dan kondisi keairan pada lereng. Data struktur bidang diskontinuitas yang didapatkan di lapangan, selanjutnya diplotkan dalam stereografi untuk dilakukan analisis kinematik lereng batuan untuk mendapatkan jenis longsor batuan yang akan terjadi.

Penilaian kualitas massa batuan berdasarkan klasifikasi RMR (1989) dan GSI dilakukan 
terhadap 4 lereng (lihat Gambar 1a). Dalam bidang rock engineering, sistem klasifikasi yang banyak digunakan adalah $R M R$ yang dikembangkan oleh Bieniawski (1989), Q-sistem oleh Barton, et al. (1974), dan GSI yang dibuat oleh Hoek dan Brown (1997). Namun penelitian ini hanya mengunakan klasifikasi massa batuan $R M R$ dan GSI untuk menilai kualitas massa batuan dan memperkirakan nilai modulus deformasinya.

\section{RMR (Rock Mass Rating)}

Pada $R M R_{89}$, Bieniawski (1989) mengusulkan beberapa parameter untuk menilai kualitas massa batuan, diantaranya: kekuatan batuan utuh, nilai $R Q D$ (rock quality designation), spasi bidang diskontinuitas/rekahan, kondisi bidang diskontinuitas/rekahan, dan kondisi air pada batuan. Berikut ini penjelasan detail masingmasing parameter yang digunakan.

\section{Kekuatan Batuan Utuh (Strength of Intact Rock)}

Kekuatan batuan utuh didapatkan dari hasil pengujian batuan utuh yang diambil dari lereng yang diteliti. Dalam sistem $R M R$, nilai kekuatan batuan utuh bisa didapatkan menggunakan alat uji tekan, alat uji point load, Schmidt hammer dan estimasi lapangan mengunakan palu geologi, nilai akhir dari pengujian tersebut berupa nilai $U C S$ (uniaxial compressive strength). Pada penelitian ini, perhitungan nilai $U C S$ menggunakan metode estimasi lapangan berdasarkan hasil penelitian Hoek dan Brown (1997) dan uji Schmidt hammer. Cara estimasi UCS di lapangan dapat dilihat pada Tabel 1.

Selain mengunakan metode estimasi lapangan, uji Schmidt hammer juga dilakukan pada sampel batuan untuk menghitung nilai UCS berdasarkan rumus Katz et al. (2000) sebagaimana ditunjukkan pada persamaan 1. Nilai RN menunjukkan nilai rebound berdasarkan uji Schmidt hammer jenis N.

$$
U C S=2.21 e^{(0,07 R N)}
$$

$R Q D$ (Rock Quality Designation)

$R Q D$ pertama sekali diperkenalkan oleh Deere (1968) sebagai sebuah metode untuk menilai kualitas batuan berdasarkan data bor. Nilai $R Q D$ memberikan nilai persentase kerapatan bidang diskontinuitas antar batuan yang lebih panjang

Tabel 1. Estimasi kekuatan batuan utuh setelah dimodifikasi dari Hoek dan Brown (1997).

\begin{tabular}{lccc}
\hline \multicolumn{1}{c}{$\begin{array}{c}\text { Cara Estimasi Kekuatan Batuan Utuh } \\
\text { di Lapangan }\end{array}$} & Terminologi & $\begin{array}{c}\text { Nilai } \text { UCS } \\
\text { (MPa) }\end{array}$ & $\begin{array}{c}\text { Nilai Point Load Index } \\
\text { (MPa) }\end{array}$ \\
\hline $\begin{array}{l}\text { Spesimen batuan hanya terkelupas setelah } \\
\text { dipukul berkali-kali dengan palu geologi }\end{array}$ & $\begin{array}{c}\text { Sangat-sangat } \\
\text { Keras }\end{array}$ & $>250$ & $>10$ \\
$\begin{array}{l}\text { Spesimen batuan harus dipukul berkali-kali } \\
\text { menggunakan palu geologi agar retak. }\end{array}$ & Sangat Keras & $100-250$ & $4-10$ \\
$\begin{array}{l}\text { Spesimen batuan harus dipukul lebih dari } \\
\text { satu kali menggunakan palu geologi agar } \\
\text { retak. }\end{array}$ & Keras & $50-100$ & $2-4$ \\
$\begin{array}{l}\text { Spesimen batuan dapat retak dengan sekali } \\
\text { pukul menggunakan palu geologi namun } \\
\text { belum bisa dikumpas menggunakan pisau } \\
\text { saku. }\end{array}$ & Sedang & $25-50$ & $1-2$ \\
$\begin{array}{l}\text { Spesimen batuan dapat dikupas } \\
\text { menggunakan pisau saku namun agak susah } \\
\text { dan spesimen bisa dilubangi/lekuk } \\
\text { menggunakan ujung palu geologi batuan } \\
\text { beku. }\end{array}$ & Lunak & $5-25$ & - \\
$\begin{array}{l}\text { Dengan mudah bisa dikupas menggunakan } \\
\text { pisau saku dan hancur dengan sedikit } \\
\text { pukulan dengan palu geologi. }\end{array}$ & Sangat Lunak & $1-5$ & \\
$\begin{array}{l}\text { Bisa dilubangi/dilekuk menggunakan kuku } \\
\text { tangan. }\end{array}$ & Sangat-sangat \\
\hline
\end{tabular}


dari $10 \mathrm{~cm}$ (4 inch) dibagi dengan panjang total data bor (Deere 1968). Untuk mendapatkan nilai $R Q D$ pada sebuah singkapan batuan, Priest dan Hudson (1993) mengusulkan pendekatan berdasarkan nilai banyaknya bidang diskontinuitas per meter atau frekuensi bidang diskontinuitas $(\lambda)$, sebagaimana ditunjukkan oleh persamaan 2 di bawah ini.

$$
R Q D=100 e^{-0.1 \lambda}(0.1 \lambda+1)
$$

\section{Spasi Bidang Diskontinuitas}

Dalam bidang rock engineering, bidang diskontinuitas termasuk diantaranya bidang perlapisan batuan, kekar, patahan, dan rekahan permukaan lainnya. Nilai spasi bidang diskontinuitas merupakan jarak tegak lurus antara kedua bidang dan harus diukur pada setiap kelompok bidang diskontinuitas (Singh dan Goel, 1999).

\section{Kondisi Bidang Diskontinuitas}

Kondisi bidang diskontinuitas yang diukur pada massa batuan berupa kekasaran bidang (roughnesss), bukaan bidang (aperture), kemenerusan bidang (persistence), material isian bidang (infilling material), dan derajat pelapukan bidang (degree of weathering). Pengamatan kondisi kekasaran dan derajat pelapukan bidang merujuk ke deskripsi yang dibuat oleh Brown (1981). Pemberian bobot masing-masing parameter tersebut dapat dilihat pada Tabel 2 di bawah ini.

\section{Kondisi Air Tanah}

Kondisi air tanah akan mempengaruhi kekuatan geser bidang dikontinuitas akibat tekanan air pada bidang tersebut. Untuk kajian nilai $R M R$ pada terowongan, perhitungan kondisi air bisa dilakukan dengan cara mengamati jumlah per-liter per-menit pada setiap jarak 10 meter panjang terowongan dan hal yang sama bisa diterapkan pada analisis kondisi air tanah di lereng. Pada tingkatan praktis, pengamatan air tanah cukup berdasarkan deskripsi kering, lembab, berair, basah, dan mengalir (Singh dan Goel, 1999). Pembagian bobot kondisi air tanah dan keempat parameter $R M R$ yang lain, dapat dilihat pada Tabel 3.

\section{Geological Strength Index (GSI)}

Sistem klasifikasi GSI diperkenalkan oleh Hoek (1994) untuk menganalisis kualitas massa batuan yang keras dan lunak. Penilaian GSI dilakukan berdasarkan investigasi visual kondisi geologi dengan cara mencocokan kondisi massa batuan dengan diagram GSI yang dibuat oleh Hoek (1994). Pengamatan visual sistem GSI juga mempertimbangkan 2 paramater utama yaitu: kondisi bidang diskontinuitas dan kerapatan bidang diskontinuitas atau struktur geologi. Sering kali, investigasi visual nilai GSI memberikan hasil yang subjektif dan sangat bergantung pada pengalaman ahli geologi yang melakukan survei. Untuk menghindari subjektifitas hasil GSI, Sonmez dan Ulusay (1999), Cai et al. (2004), Hoek et al. (2013) membuat sebuah pendekatan kuantitatif, sehingga akan menghasilkan hasil yang lebih objektif.

Hoek et al. (2013) mengusulkan 5 paramater untuk menilai kondisi bidang diskontinuitas. Kelima parameter kondisi bidang (Jcond) tersebut sama dengan parameter yang diusulkan oleh Bieniawski (1989) dengan total bobot 30. Bobot masing-masing parameter tersebut dapat dilihat

Tabel 2. Paramater dan bobot kondisi bidang diskontinuitas (Bieniawski, 1989).

\begin{tabular}{lccccc}
\hline Kemenerusan & $<1 \mathrm{~m}$ & $1-3 \mathrm{~m}$ & $3-10 \mathrm{~m}$ & $10-20 \mathrm{~m}$ & $>20 \mathrm{~m}$ \\
Bobot & 6 & 4 & 2 & 1 & 0 \\
\hline Bukaan & None & $<0,1 \mathrm{~mm}$ & $0,1-1,0 \mathrm{~mm}$ & $1-5 \mathrm{~mm}$ & $>5 \mathrm{~mm}$ \\
Bobot & 6 & 5 & 4 & 1 & 0 \\
\hline Kekasaran & Very kasar & Kasar & Sedikit kasar & Halus & Licin \\
Bobot & 6 & 5 & 3 & 1 & 0 \\
\hline Isian & None & Isian keras $<5$ & Isian keras $>5$ & Isian lunak $<5$ & Isian lunak $>5$ \\
& & mm & mm & mm & 0 \\
Bobot & 6 & 4 & 2 & 2 & Terubahkan \\
\hline Pelapukan & Tidak lapuk & Pelapukan & Pelapukan & Pelapukan Tinggi & 0 \\
Bobot & 6 & Ringan & Sedang & & 0 \\
\hline
\end{tabular}


Tabel 3. Paramater klasifikasi $R M R_{\text {basic }}$ dan pembobotannya berdasarkan Bieniawski (1989).

\begin{tabular}{|c|c|c|c|c|c|c|c|c|c|}
\hline & \multicolumn{2}{|c|}{ Paramater } & \multicolumn{7}{|c|}{ Kondisi dan Rentang Penilaian } \\
\hline \multirow[t]{3}{*}{1} & \multirow[t]{2}{*}{$\begin{array}{l}\text { Kekuatan } \\
\text { Batuan } \\
\text { Utuh }\end{array}$} & \multirow{2}{*}{$\begin{array}{l}\text { Indeks } \\
\text { Kekuatan } \\
\text { Point Load } \\
\text { Uniaxial } \\
\text { Compressive } \\
\text { Strength } \\
\text { (UCS) }\end{array}$} & \multirow{2}{*}{$\begin{array}{l}>10 \mathrm{MPa} \\
>250 \mathrm{MPa}\end{array}$} & \multirow{2}{*}{$\begin{array}{c}4-10 \mathrm{MPa} \\
100-250 \\
\mathrm{MPa}\end{array}$} & \multirow{2}{*}{$\begin{array}{c}2-4 \mathrm{MPa} \\
\\
50-100 \\
\mathrm{MPa}\end{array}$} & \multirow{2}{*}{$\begin{array}{c}1-2 \mathrm{MPa} \\
25-50 \\
\mathrm{MPa}\end{array}$} & \multicolumn{3}{|c|}{$\begin{array}{c}\text { Kekuatan rendah tidak } \\
\text { menggunakan point } \\
\text { load test }\end{array}$} \\
\hline & & & & & & & $\begin{array}{l}5-25 \\
\mathrm{MPa}\end{array}$ & $\begin{array}{l}1-5 \\
\mathrm{MPa}\end{array}$ & $\begin{array}{c}<1 \\
\mathrm{MPa}\end{array}$ \\
\hline & Bobot & & 15 & 12 & 7 & 4 & 2 & 1 & 0 \\
\hline 2 & \multicolumn{2}{|c|}{$\begin{array}{l}\text { Nilai Kualitas Inti Bor } \\
(R Q D) \\
\text { Bobot }\end{array}$} & $90-100 \%$ & $75-90 \%$ & $50-75 \%$ & $25-50 \%$ & & $<25 \%$ & \\
\hline 3 & \multicolumn{2}{|c|}{$\begin{array}{l}\text { Spasi Bidang } \\
\text { Ketidakmenerusan } \\
\text { Bobot }\end{array}$} & $>2 \mathrm{~m}$ & $\begin{array}{c}0,6-2 \mathrm{~m} \\
15\end{array}$ & $\begin{array}{c}200-600 \\
\mathrm{~mm} \\
10\end{array}$ & $\begin{array}{c}60-200 \\
\mathrm{~mm} \\
8\end{array}$ & & $<60 \mathrm{mr}$ & \\
\hline \multirow[t]{2}{*}{4} & \multirow{2}{*}{\multicolumn{2}{|c|}{$\begin{array}{l}\text { Kondisi Bidang } \\
\text { Ketidakmenerusan }\end{array}$}} & $\begin{array}{l}\text { Sangat } \\
\text { kasar, } \\
\text { dinding } \\
\text { segar, } \\
\text { tidak } \\
\text { menerus, } \\
\text { rapat }\end{array}$ & $\begin{array}{c}\text { Kasar, } \\
\text { terbuka }<1 \\
\text { mm, dinding } \\
\text { sedikit lapuk }\end{array}$ & $\begin{array}{c}\text { Sedikit } \\
\text { kasar, <1 } \\
\text { mm, } \\
\text { dinding } \\
\text { sangat } \\
\text { lapuk }\end{array}$ & $\begin{array}{c}\text { Terisi, } \\
\text { tebal }<5 \\
\text { mm, } \\
\text { terbuka } \\
1-5 \mathrm{~mm}, \\
\text { menerus }\end{array}$ & \multicolumn{3}{|c|}{$\begin{array}{c}\text { Terisi material lunak }>5 \\
\mathrm{~mm}, \text { terbuka }>5 \mathrm{~mm}, \\
\text { menerus }\end{array}$} \\
\hline & & & 30 & 25 & 20 & 10 & & 0 & \\
\hline \multirow[t]{2}{*}{5} & Keairan & $\begin{array}{l}\text { Aliran per } 10 \\
\text { m panjang } \\
\text { terowongan } \\
\text { Tekanan Air } \\
\text { Kondisi } \\
\text { Umum }\end{array}$ & $\begin{array}{c}0 \\
\text { Kering }\end{array}$ & $\begin{array}{c}<0,1 \\
\text { Lembab }\end{array}$ & $\begin{array}{l}0,1-0,2 \\
\text { Berair }\end{array}$ & $\begin{array}{l}0,2-0,5 \\
\text { Basah }\end{array}$ & & $\begin{aligned}>0,5 \\
\text { Mengal }\end{aligned}$ & \\
\hline & Bobot & & 15 & 10 & 7 & 4 & & 0 & \\
\hline
\end{tabular}

pada Tabel 2. Untuk menilai kerapatan bidang diskontinuitas, Hoek et al. (2013) menggunakan parameter $R Q D$ yang diusulkan oleh Deere (1968), perhitungannya bisa mengunakan persamaan Priest dan Hudson (1993) yang ditunjukkan pada persamaan 2. Diagram GSI menggunakan parameter kondisi bidang diskontinuitas $\left(\right.$ Jcond $\left._{89}\right)$ dan $R Q D$ dapat dilihat pada Gambar 2. Selain menggunakan diagram, nilai GSI juga bisa dihitung menggunakan persamaan 3 berikut ini.

$$
G S I=1.5 \text { Jcond }_{89}+R Q D / 2
$$

Sering kali nilai $R Q D$ yang didapatkan lebih besar dari chart GSI yang dikembangkan oleh Hoek et al. (2013) untuk nilai $R Q D$ maksimal $80 \%$. Untuk nilai $R Q D$ lebih besar dari $80 \%$, Winn dan Wong (2019) mengusulkan persamaan 4 yang juga akan digunakan dalam penelitian ini.

$$
G S I=1.5 \mathrm{Jcond}_{89}+\mathrm{RQD} / 3
$$

Penelitian ini menghitung estimasi nilai modulus deformasi massa batuan $\left(E_{r m}\right)$ yang didapatkan dari nilai GSI menggunakan persamaan (5) yang dikembangkan Hoek dan Brown (2019).

$$
E_{r m}=10^{5} \frac{1-D / 2}{1+\exp \frac{75+25 D-G S I}{11}}
$$

$D$ merupakan disturbing factor berdasarkan ketentuan yang dikeluarkan oleh Hoek dan Brown (1997, 2019). Untuk lereng batuan yang dipotong dengan cara perledakan ringan dan mekanik, nilai D adalah 1.

\section{HASIL DAN PEMBAHASAN}

\section{Analisis Kinematik Lereng Batu}

Berdasarkan hasil akuisisi data struktur massa batuan di lapangan, didapatkan data bidang diskontinuitas dari lintasan scanline sepanjang 75-145 meter di lereng 1 sampai dengan lereng 4, lokasi masing-masing lereng dapat dilihat pada Gambar 1.

\section{Lereng 1}

Lereng 1 memiliki kemiringan lereng $70^{\circ}$ dan menghadap ke arah $\mathrm{N} 289^{\circ} \mathrm{E}$ atau ke arah barat laut. Pada lereng ini terdapat 4 joint set bidang 


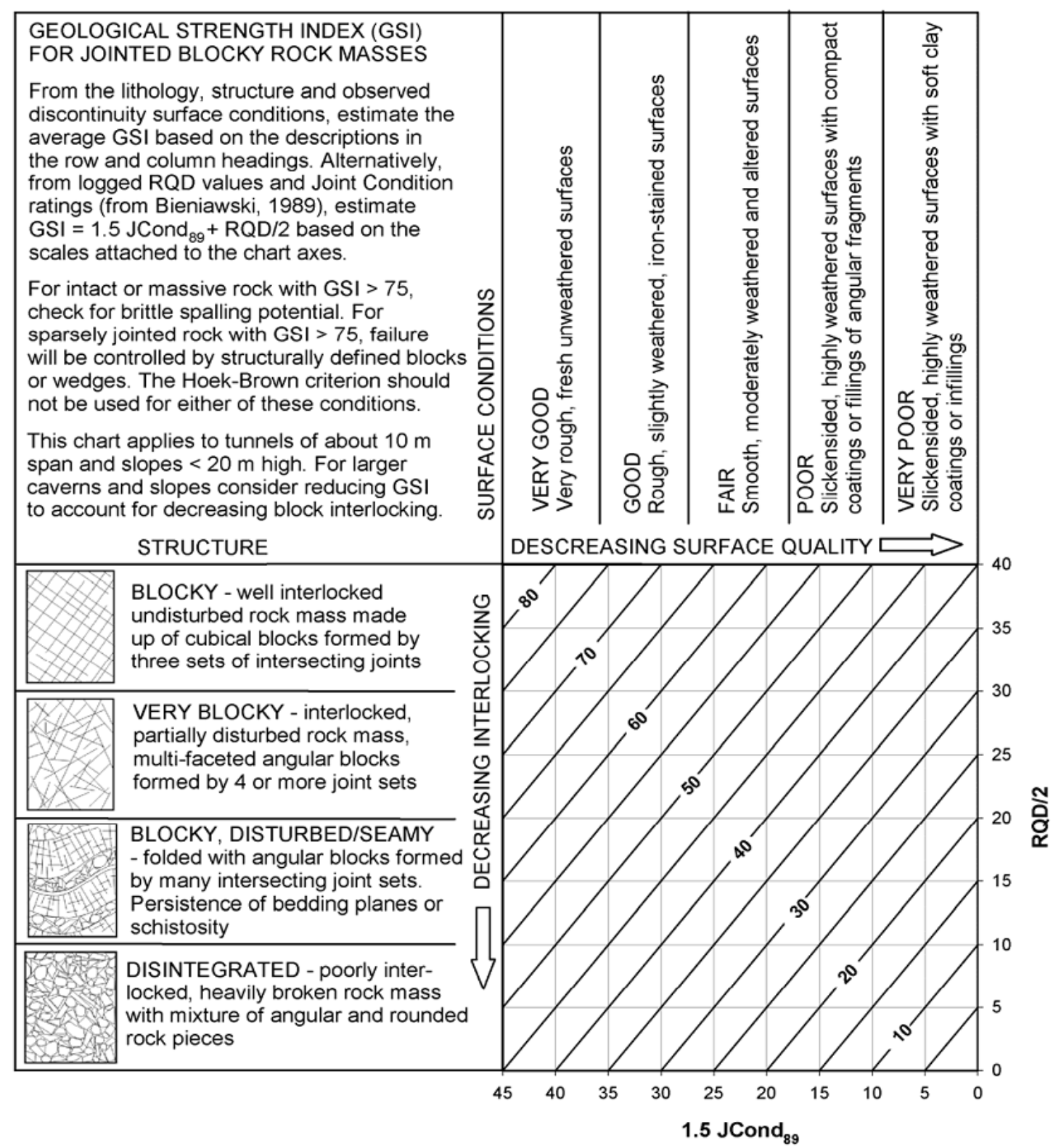

Gambar 2. Diagram GSI yang sudah menggunakan parameter kondisi bidang diskontinuitas dan $R Q D$ berdasarkan Hoek et al. (2013).

diskontinuitas memiliki arah berbeda terhadap lereng (lihat Gambar 3a). Longsor batuan yang mungkin terjadi di lereng adalah longsor jenis planar, hal ini dikarenakan bidang J2 memiliki arah jurus yang hampir sama dengan arah jurus lereng. Selain itu, longsor jenis gulingan juga kemungkinan akan terjadi di lereng 1 kerena bidang J3 memiliki arah yang berlawanan dengan arah muka lereng.

\section{Lereng 2}

Lereng 2 menghadap kearah $\mathrm{N} 307^{\circ} \mathrm{E}$ dengan kemiringan $60^{\circ}$ dan memiliki 2 buah joint set yang saling memotong di tengah lereng (lihat Gambar $3 b)$. Perpotongan antara $\mathbf{J} 1$ dengan $\mathbf{J} 2$ di lereng 2 membentuk blok baji yang menghadap tidak searah dengan muka lereng. Akibat perpotongan kedua bidang ini, longsor jenis baji masih dimungkinan terjadi di lereng 2 .

\section{Lereng 3}

Lereng 3 menghadap kearah $\mathrm{N} 345^{\circ} \mathrm{E}$ dengan arah jurus $\mathrm{N} 255^{\circ} \mathrm{E}$ dan kemiringan lereng $60^{\circ}$. Lereng 3 memiliki 4 bidang joint set dan paling banyak didominasi oleh joint set $\mathrm{J} 1$ yang memiliki arah $\mathrm{N}$ $180^{\circ} \mathrm{E}$ dengan kemiringan bidang $80^{\circ}$ (lihat 

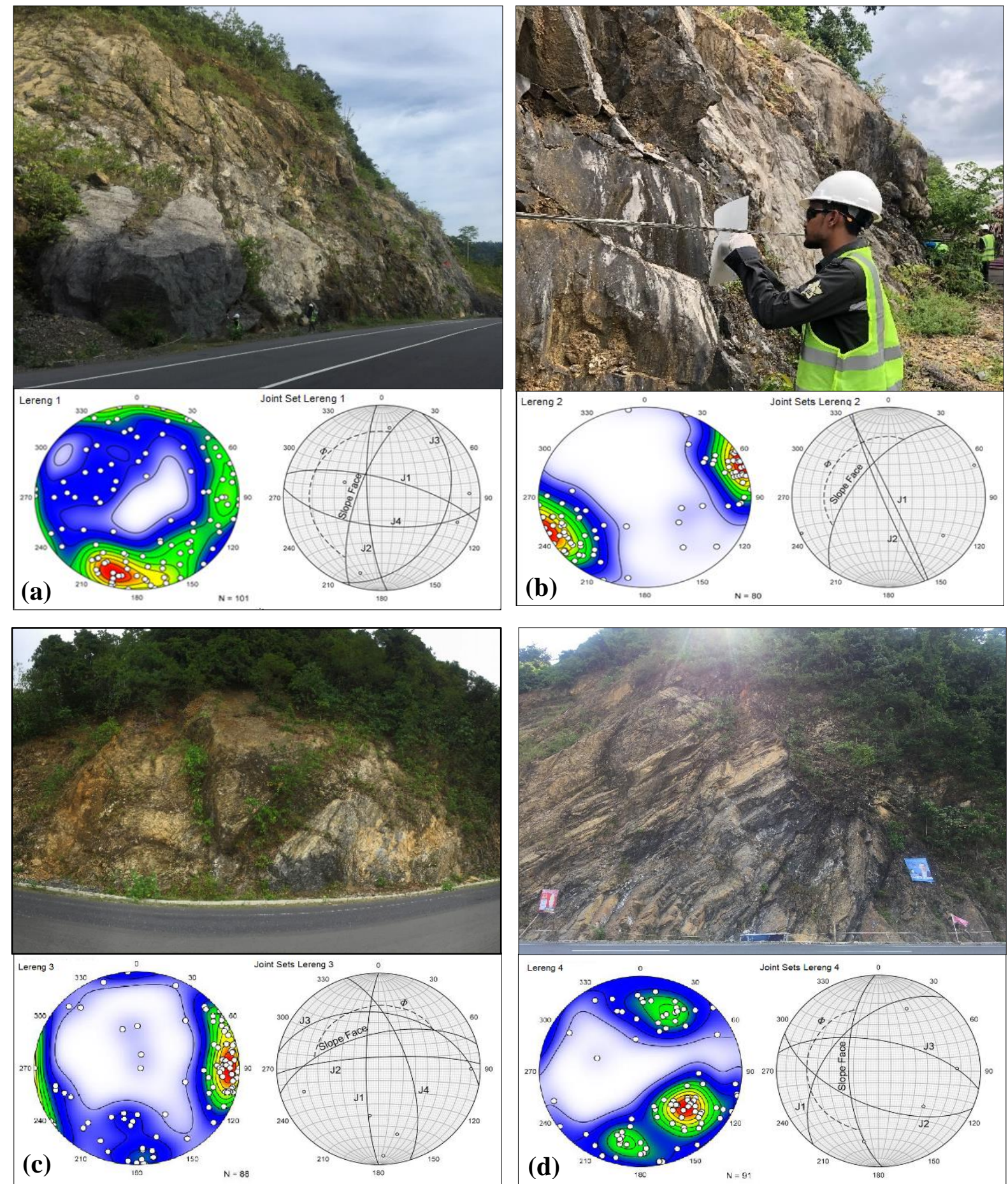

Gambar 3. Foto lereng dan data stereografi yang menunjukkan arah dan jumlah joint sets, muka lereng (slope face), dan sudut geser $(\Phi)$, (a) Lereng 1, (b) Lereng 2, (c) Lereng 3, dan (d) Lereng 4.

Gambar 3c). Bidang J1 dengan J3 saling berpotongan sehingga membentuk blok baji sehingga Lereng 3 rentan terhadap terjadinya longsor jenis baji. Selain itu, bidang J2 memiliki arah yang hampir sama dengan arah muka lereng dengan sudut kemiringan bidang $\mathrm{J} 2$ sebesar $20^{\circ}$. Kemiringan bidang $\mathrm{J} 2$ lebih kecil dari sudut geser dalam sehingga longsor jenis planar tidak akan terjadi di lereng 3. 


\section{Lereng 4}

Lereng 4 merupakan lereng terakhir yang diinvestigasi dalam penelitian ini. Lereng menghadap kearah $\mathrm{N} 268^{\circ} \mathrm{E}$ (barat) dengan arah jurus $\mathrm{N} 178^{\circ} \mathrm{E}$ pada kemiringan lereng $66^{\circ}$ (lihat Gambar 3d). Pada lereng ini ditemukan 3 bidang joint set yang memiliki arah beragam. Data bidang diskontinuitas batuan terbanyak adalah bidang $\mathrm{J} 1$. Perpotongan antara bidang $\mathrm{J} 1$ dengan bidang $\mathrm{J} 2$ membentuk blok baji sehingga memungkinkan untuk terjadinya longsor jenis baji.

\section{RMR (Rock Mass Rating)}

Nilai kekuatan batuan didapat berdasarkan hasil estimasi lapangan pada batuan utuh dan hasil uji
Schmidt hammer. Hasil estimasi lapangan menggunakan palu geologi menunjukkan bahwa kekuatan batuan utuh keempat lereng masuk kategori sedang karena bisa dipecahkan dengan sekali pukul menggunakan palu geologi. Kondisi ini memberikan nilai estimasi UCS sekitar 25-50 MPa. Hasil uji Schmidt hammer memberikan nilai rebound 41, sehingga hasil perhitungan menggunakan persamaan 1 memberikan nilai UCS sebesar $39 \mathrm{Mpa}$. Nilai estimasi lapangan dan uji Schmidt hammer untuk kekuatan batuan utuh memberikan bobot 4 untuk parameter UCS.

Banyaknya bidang diskontinuitas pada lereng akan direpresentasikan oleh data $R Q D$ dan spasi bidang diskontinuitas. Berdasarkan hasil

Tabel 4. Nilai $R M R$ lereng yang diteliti di Kecamatan Leupung km 27 hingga km 30.

\begin{tabular}{|c|c|c|c|c|c|}
\hline No. & Parameter $R M R$ & Lereng 1 & Lereng 2 & Lereng 3 & Lereng 4 \\
\hline \multirow[t]{2}{*}{1.} & Kekuatan Batuan Utuh & 25-50 Мра & 25-50 Мра & 25-50 Mpa & 25-50 Мра \\
\hline & Bobot (R1) & 4 & 4 & 4 & 4 \\
\hline \multirow[t]{2}{*}{2.} & $R Q D$ & $99,0 \%$ & $99,4 \%$ & $98,5 \%$ & $98,6 \%$ \\
\hline & Bobot (R2) & 20 & 20 & 20 & 20 \\
\hline \multirow[t]{2}{*}{3.} & Spasi Bidang Diskontinuitas & $200-600 \mathrm{~mm}$ & $0,6-2 \mathrm{~m}$ & $200-600 \mathrm{~mm}$ & $200-600 \mathrm{~mm}$ \\
\hline & Bobot (R3) & 10 & 12 & 10 & 10 \\
\hline \multirow{12}{*}{4.} & $\begin{array}{l}\text { Kondisi Bidang } \\
\text { Diskontinuitas }\end{array}$ & & & & \\
\hline & Kemenerusan & $3-10 \mathrm{~m}$ & $3-10 \mathrm{~m}$ & $3-10 \mathrm{~m}$ & $3-10 \mathrm{~m}$ \\
\hline & Bobot & 2 & 2 & 2 & 2 \\
\hline & Bukaan & $0,1-1,0 \mathrm{~mm}$ & $0,1-1,0 \mathrm{~mm}$ & $0,1-1,0 \mathrm{~mm}$ & $0,1-1,0 \mathrm{~mm}$ \\
\hline & Bobot & 2 & 2 & 2 & 2 \\
\hline & Kekasaran & Sedikit kasar & Sedikit kasar & Sedikit kasar & Sedikit kasar \\
\hline & Bobot & 3 & 4 & 4 & 4 \\
\hline & Isian & $\begin{array}{c}\text { Isian lunak < } \\
5 \mathrm{~mm} \\
\end{array}$ & $\begin{array}{c}\text { Isian lunak < } \\
5 \mathrm{~mm} \\
\end{array}$ & $\begin{array}{c}\text { Isian keras }>5 \\
\mathrm{~mm}\end{array}$ & $\begin{array}{c}\text { Isian keras }>5 \\
\mathrm{~mm}\end{array}$ \\
\hline & Bobot & 2 & 2 & 3 & 3 \\
\hline & Pelapukan & Sedang & Sedang & Sedang & Sedang \\
\hline & Bobot & 2 & 2 & 2 & 3 \\
\hline & $\begin{array}{l}\text { Bobot Total Kondisi Bidang } \\
\text { (R4) }\end{array}$ & 11 & 13 & 13 & 14 \\
\hline \multirow[t]{2}{*}{5.} & Kondisi Air Tanah & Kering & Kering & Kering & Kering \\
\hline & Bobot (R5) & 15 & 15 & 15 & 15 \\
\hline \multicolumn{2}{|c|}{$R M R_{b}=\mathrm{R} 1+\mathrm{R} 2+\mathrm{R} 3+\mathrm{R} 4+\mathrm{R} 5$} & 60 & 64 & 60 & 61 \\
\hline \multicolumn{2}{|c|}{ Kategori Kelas Massa Bantuan } & Good Rock & Good Rock & Good Rock & Good Rock \\
\hline \multicolumn{2}{|r|}{ Kohesi Massa Batuan (kPa) } & $300-400$ & $300-400$ & $300-400$ & $300-400$ \\
\hline \multicolumn{2}{|r|}{ Sudut Geser Massa Batuan $\left(^{\circ}\right)$} & $35-45$ & $35-45$ & $35-45$ & $35-45$ \\
\hline
\end{tabular}


pengamatan lapangan, bidang diskontinuitas yang terdapat lokasi penelitian terbentuk akibat bidang perlapisan batugamping lempungan dan bidang rekahan akibat proses tektonik. Berdasarkan hasil perhitungan menggunakan persamaan 2 maka didapatkan nilai $R Q D$ sebesar $99,0 \%, 99,4 \%$, $98,5 \%$, dan $98.6 \%$ secara berurutan untuk lereng 1 sampai 4. Tingginya nilai $R Q D$ ini sangat dipengaruhi oleh jarak antar bidang diskontinuitas antara $0.5-0.9$ meter sehingga bobot nya antara 10-12. Untuk nilai $R Q D$ dan spasi bidang diskontinuitas, ketiga lereng memiliki bobot yang sama yaitu 20 untuk $R Q D$ dan $10-12$ untuk spasi (lihat Tabel 4).

Kondisi bidang diskontinuitas untuk keempat lereng menunjukkan nilai yang tidak bergitu berbeda. Hal ini dikarenakan keempat lereng terbentuk dari batuan yang sama dengan memiliki umur yang sama. Selain itu, semua lereng dipotong pada waktu yang hampir bersamaan sehingga apabila terjadi pelapukan akibat berinteraksi dengan atmosfer maka derajat pelapukan juga sama. Lereng 1, 2, 3 dan 4 memiliki kemenerusan atau panjang bidang diskontinuitas sebesar 3-10 meter dengan bukaan bidang rata-rata sebesar $0.1-1 \mathrm{~mm}$. Tingkat kekasaran bidang diskontinuitas diamati berdasarkan standar yang dibuat oleh Brown (1981) dan hasilnya menunjukkan kondisi bidang diskontinuitas sedikit kasar dengan bobot 4 untuk masing-masing lereng. Bidang diskontinuitas terisi oleh mineral kalsit dan sebagian lempung, sehingga diberikan bobot 2. Untuk tingkat pelapukan, penelitian ini merujuk ke standar pelapukan yang dikeluarkan oleh Brown (1981). Tingkat pelapukan batugamping lempungan di masing-masing lereng adalah sedang. Pelapukan sedang ditandai dengan pelapukan meluas dari bidang diskontinuitas lebih besar dari $20 \%$ dari pada spasi. Pada saat survei, kondisi keairan batuan pembentuk lereng kering sehingga bobotnya menjadi 15 .

Nilai UCS, $R Q D$, spasi bidang, kondisi bidang, dan kondisi air menunjukkan nilai yang hampir sama sehingga menjadikan nilai $R M R$ keempat lereng hampir sama, 60, 64, 60, dan 61 secara berurutan. Berdasarkan standar klasifikasi Bieniawski(1989) nilai $R M R$ 60-64, termasuk kategori good rock yang memiliki nilai kohesi massa batuan $300-400 \mathrm{kPa}$, sudut geser massa batuan $35^{\circ}-45^{\circ}$.

\section{GSI (Geological Strength Index)}

Pada Tabel 5 di bawah, dapat dilihat hasil perhitungan GSI berdasarkan nilai $R Q D$ dan kondisi bidang diskontinuitas (Jcond 89 ) yang dibuat oleh Bieniawski (1989). Nilai $\lambda$ merupakan banyaknya bidang atau frekuensi bidang dan digunakan untuk menghitung $R Q D$. Nilai $R Q D$ yang didapatkan cukup tinggi, hal ini dikarenakan jarak antar bidang diskontinuitas antara 0,5-0,9 meter. Nilai Jcond $_{89}$ lereng dapat dilihat pada Tabel 4 No. 4 dan hasil akhir perhitungan GSI untuk Lereng 1, 2, 3, dan 4 secara berurutan dapat dilihat pada Tabel 5 .

Hasil estimasi modulus deformasi massa batuan $\left(E_{r m}\right)$ keempat lereng menggunakan persamaan 5 dapat dilihat pada Tabel 5. Berdasarkan pendekatan klasifikasi massa batuan GSI dan persamaan 5 maka lereng 1 sampai 4 memiliki nilai $E_{r m}$ yang hampir sama, yaitu $50 \mathrm{GPa}$.

Tabel 5. Nilai GSI dan modulus deformasi massa batuan lereng yang diteliti km 27 hingga km 30 di Kecamatan Leupung, Aceh Besar.

\begin{tabular}{|c|c|c|c|c|}
\hline $\begin{array}{l}\text { Parameter GSI menurut } \\
\text { Hoek, et al. (2013) }\end{array}$ & Lereng 1 & Lereng 2 & Lereng 3 & Lereng 4 \\
\hline$\lambda$ & 1,52 & 1,11 & 1,85 & 1,75 \\
\hline$R Q D / 3$ & 33,0 & 33,1 & 32,8 & 32,9 \\
\hline Jcond (lihat R4 di Tabel 4) & 11 & 13 & 13 & 14 \\
\hline 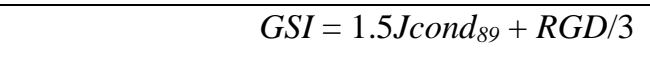 & 50 & 51 & 52 & 54 \\
\hline $\mathrm{D}$ & 1 & 1 & 1 & 1 \\
\hline Modulus Deformasi Massa Batuan $\left(E_{r m}\right) \mathrm{GPa}$ & 50,099 & 50,085 & 50,076 & 50,066 \\
\hline
\end{tabular}




\section{KESIMPULAN DAN SARAN}

Metode scanline yang digunakan dalam penelitian ini telah berhasil mendata struktur geologi dan kondisi bidang diskontinuitas pada masingmasing lereng. Analisis kinematik lereng lereng batu berdasarkan hasil plot stereografi menunjukkan bahwa longsor batu jenis planar dan gulingan akan terjadi di Lereng 1, longsor batu jenis baji akan terjadi di Lereng 2, longsor planar dan baji akan di Lereng 3, dan longsor jenis baji di Lereng 4.

Berdasarkan hasil analisis klasifikasi massa batuan $R M R$, nilai kualitas massa batuan masingmasing lereng adalah 60,64, 60, dan 61 secara berurutan untuk lereng 1, 2, 3, dan 4. Kondisi nilai $R M R$ yang hampir sama disebabkan lereng yang diteliti memiliki jenis batuan yang sama, terbentuk pada umur dan proses geologi yang sama. Selain itu, lereng 1, 2, 3, dan 4 dipotong pada tahun 2007 untuk membuat jalur jalan baru.

Hasil perhitungan nilai GSI menunjukkan nilai yang hampir sama yaitu 50, 51, 52, dan 54 secara berurutan. Kesamaan nilai GSI ini dikarenakan keempat lereng memiliki nilai $R Q D$ dan kondisi bidang diskontinuitas yang hampir sama. Nilai GSI ini bisa digunakan untuk menghitung estimasi nilai modulus deformasi massa batuan $\left(E_{r m}\right)$ menggunakan persamaan dari Hoek dan Brown (2019) dan hasilnya sebesar 50,099 GPa untuk Lereng 1, 50,085 GPa untuk Lereng 2, 50,076 GPa untuk Lereng 3, dan 50,066 GPa untuk Lereng 4. Analisis kinematik telah memberikan informasi jenis longsor batuan yang kemungkinan akan terjadi pada keempat lereng yang diteliti. Upaya pencegahan bencana longsor batuan harus dilakukan guna memastikan lancarnya transportasi antara ibu kota Provinsi Aceh dengan kabupaten-kabupaten di barat dan selatan. Ada banyak metode pencegahan longsor batuan yang bisa dilakukan, diantaranya rock removal atau menurunkan blok-blok batuan yang kemungkinan akan jatuh terutama untuk longsor jenis gulingan. Metode rock removal merupakan metode yang paling murah. Selain itu, pemasangan rock bolt dalam upaya slope protection juga bisa dilakukan pada bidang-bidang batuan yang kemungkinan mengalami longsor jenis planar dan baji. Dalam penelitian ini juga didapatkan nilai $R M R$ dan $G S I$ yang menunjukkan kualitas massa batuan pembentuk lereng. Nilai $R M R$ dan GSI ini bisa berubah seiring waktu karena ada beberapa parameter seperti tingkat pelapukan dan bukaan bidang yang nilainya bisa terus berkurang. Saat ini nilai $R M R$ dan GSI keempat lereng masih tergolong bagus (good rock) namun nilai ini akan berkurang seiring waktu, terlebih lagi batugamping yang menjadi pembentuk keempat lereng.

\section{UCAPAN TERIMAKASIH}

Penulis mengucapkan terima kasih banyak kepada LPPM Universitas Syiah Kuala yang telah menyediakan dana penelitian skema Penelitian Lektor tahun 2019 dan semua pihak yang turut membantu terlaksananya penelitian ini.

\section{DAFTAR PUSTAKA}

Barber, A. J., 2000. The Origin of the Woyla Terranes in Sumatra dan the Late Mesozoic Evolution of the Sundaldan Margin. Journal of Asian Earth Science, 18(6), pp. 713-738.

Barber, A. J. dan Crow, M. J., 2005. Pre-Tertiary Stratigraphy. In: A. J. Barber, M. J. Crow dan J. S. Milson, eds. Sumatra: Geology, Resources, dan Tectonic Evolution. London: Geological Society, p. 41.

Barton, N. R., Lien, R. dan Lunde, J., 1974. Engineering Classification of Rock Masses for the Design of Tunnel Support. Rock Mech, 6(4), pp. 189-239.

Basahel, H. dan Mitri, H., 2017. Application of Rock Mass Classification Systems to Rock Slope Stability Assessment: A Case Studi. Journal of Rock Mechanics dan Geotechnical Engineering, 9(6), pp. 993-1009.

Bennet, J. D., Bridge, D. M., Cameron, D. R., Djunuddin, A., Ghazali, S. A., Jeffrery, D. H., . . . Whdanoyo, R., 1981. Geologic 1:250,000 Map of Banda Aceh Quadragle, Sumatra. Bandung: Geological Research dan Development Centar (GRDC).

Bieniawski, Z. T., 1989. Engineering Rock Mass Classification. New York: John Wiley \& Sons.

Brown, E. T., 1981. Rock Characterization, Testing dan Monitoring, ISRM 
Suggested Methods. Oxford: Published for the Commission on Testing Methods, International Society for Rock Mechanics by Pergamon Press.

Cai, M., Kaiser, P. K., Uno, H., Tasaka, Y., dan Minami, M., 2004. Estimation of Rock Mass Deformation Modulus dan Strength of Jointed Hard Rock Masses Using the GSI System. International Journal of Rock Mechanics dan Mining Sciences, 41(1), pp. 3-19.

Deere, D. U., 1968. Geological Considerations. Dalam: Ambraseys, Penyunt. Rock Mechanics in Engineering Practice. London: John Wiley, pp. 1-20.

Fernández-Blanco, D., Philippon, M. dan Hagke, C. V., 2016. Structure and Kinematics of the Sumatran Fault System in North Sumatra (Indonesia). Tectonophysics, Volume 693, pp. 453-464.

Grelle, G., Revellino, P., Donnarumma, A. dan Guadagno, F. M., 2011. Bedding control on Landslides: A Methodological Approach for Computer-aided Mapping Analysis. Nat. Hazards Earth Syst. Sci, $\mathrm{V}(11)$, p. 1395-1409.

Gurocak, Z., Alemdag, S. dan Zaman, M. M., 2008. Rock Slope Stability and Excavatability Assessment of Rocks at the Kapikaya Dam Site, Turkey. Engineering Geology, Volume 96, pp. 17-27.

Hoek, E., 1994. Strength of Rock and Rock Masses. ISRM New Journal, 2(2), pp. 416.

Hoek, E. dan Brown, E. T., 1997. Practical Estimates of Rock Mass Strength. International Journal of Rock Mechanics and Mining Sciences, 34(8), pp. 11651186.

Hoek, E. dan Brown, E. T., 2019. The Hoeke Brown Failure Criterion and GSI 2018 Edition. Journal of Rock Mechanics and Geotechnical Engineering, Volume 11, pp. 445-463.

Hoek, E., Carter, T. G. dan Diederichs, M. S., 2013. Quantification of the Geological
Strength Index chart. San Francisco, American Rock Mechanics Association.

Katz, O., Reches, Z. dan Roegiers, J.C., 2000. Evaluation of Mechanical Rock Properties Using a Schmidt Hammer. International Journal of Rock Mechanics and Mining sciences, 37(4), pp.723-728.

Lee, C.-Y. dan Wang, I.-T., 2011. Analysis of Highway Slope Failure by An Application of the Stereographic Projection. Taiwan, World Academy of Science, Engineering dan Technology.

McCaffrey, R., 2009. The Tectonic Framework of the Sumatran Subduction Zone. Annu. Rev. Earth Planet. Sci., Issue 37, p. 34566.

Muksin, U., Rusydy, I., Erbas, K. dan Ismail, N., 2018. Investigation of Aceh Segment dan Seulimeum Fault by Using Seismological Data; A Preliminary Result. s.l., IOP Publishing, p. 012031.

Pantelidis, L., 2009. Rock Slope Stability Assessment Through Rock Mass Classification Systems. International Journal of Rock Mechanics \& Mining Sciences, Volume 46, p. 315-325.

Priest, S. D., 1993. Discontinuity Analysis for Rock Engineering. London: Chapman dan Hall.

Rusydy, I., Al-Huda, N., Fahmi, M. dan Effendi, N., 2019. Kinematic Analysis and Rock Mass Classifications for Rock Slope Failure at USAID Highways. Structural Durability \& Health Monitoring, 13(4), pp. 379-398.

Rusydy, I., Al-Huda, N., Jamaluddin, K., Sundary, D., dan Nugraha, G. S., 2017. Analisis Kestabilan Lereng Batu di Jalan Raya Lhoknga Km 17, 8 Kabupaten Aceh Besar. RISET Geologi dan Pertambangan, 27(2), pp. 145-155.

Rusydy, I., Idris, Y., Mulkal, Muksin, U., Cummins, P., Akram, M. N., dan Syamsidik., 2020. Shallow Crustal Earthquake Models, Damage, and Loss Predictions in Banda Aceh, Indonesia. Geoenvironmental Disasters, 7(8). 
Rusydy, I., Muksin, U., Mulkal, Idris, Y., Akram, M. N., dan Syamsidik., 2018. The Prediction of Building Damages and Casualties in the Kuta Alam sub districtBanda Aceh Caused by Different Earthquake Models. s.l., AIP Publishing, p. 020012.

Rusydy, I., Sugiyanto, D., Satrio, L., Zulfahriza, Rahman, A., dan Mundanar, I., 2016. Geological Aspect of Slope Failure and Mitigation Approach in BireunTakengon Main Road, Aceh Province, Indonesia. Aceh International Journal of Science and Technology, 5(1), pp. 3037.

Siddique, T., Alam, M. M., Mondal, M. E. dan Vishal, V., 2015. Slope Mass Rating and Kinematic Analysis of Slopes Along the National Highway-58 Near Jonk, Rishikesh, India. Journal of Rock
Mechanics and Geotechnical Engineering, Volume 7, pp. 600-606.

Sieh, K. dan Natawidjaja, D., 2000. Neotectonics of the Sumatran Fault. J. Geophys. Res, 105(B12), pp. 28,295-28,326.

Singh, B. dan Goel, R. K., 1999. Rock Mass Classification (A Practical Approach in Civil Engineering). 1st ed. Oxford: Elsevler.

Sonmez, H. dan Ulusay, R., 1999. Modifications to the Geological Strength Index (GSI) and Their Applicability to Stability of Slopes. International Journal of Rock Mechanic and Mining Science, 36(6), pp. 743-760.

Wyllie, D. C. dan Mah, C. W., 2004. Rock Slope Engineering (Civil and Mining). 4th ed. London and New York: Spon Press. 
